\title{
ANALISIS FAKTOR YANG MEMPENGARUHI KEPUTUSAN PASANGAN USIA SUBUR DALAM PENGGUNAAN ALAT KONTRASEPSI DI KABUPATEN BADUNG
}

Ni Kadek Sanistya Kusuma Putri ${ }^{1}$ Sudarsana Arka ${ }^{2}$

\begin{tabular}{l}
\hline \multicolumn{1}{c}{ Article history: } \\
\hline Submitted: 29 Juni 2021 \\
Revised: 15 Juli 2021 \\
Accepted: 31 Juli 2021 \\
\\
\hline
\end{tabular}

\section{Keywords:}

Age;

Education Level;

Number of Children;

Husband's Support;

Public Perception;

\section{Kata Kunci:}

Umur;

Tingkat Pendidikan;

Jumlah Anak;

Dukungan Suami;

Persepsi Masyarakat;

\section{Koresponding:}

Fakulas Ekonomi dan Bisnis

Universitas Udayana, Bali,

Indonesia

Email:

sanistyaputri14@gmail.com

\section{Abstract}

This study aims to: 1) analyze the effect of age, education level, number of children, husband's support, role offamily planning officers, and public perception simultaneously on the decision of fertile age couples (PUS) in the use of contraceptives in Badung Regency. 2) analyze the effect of age, education level, number of children, husband's support, role of family planning officers, and partial public perception of the decision of fertile age couples (PUS) in the use of contraceptives in Badung Regency. The research population was all couples of childbearing age (PUS) in Badung Regency, with a total sample of 156 respondents determined by the slovin method. The research method used is observation, structured interviews, and in-depth interviews. The data analysis techniques used were descriptive statistics, factor analysis, and logistic regression analysis. The results of the study found that age, education level, number of children, husband's support, role of family planning officers, and public perception simultaneously had a significant effect on the use of contraceptives in Badung Regency. Then, age, number of children, husband's support, and public perception partially have a positive and significant effect on the use of contraceptives, while the level of education and the role of family planning officers partially have no significant effect on the use of contraceptives.

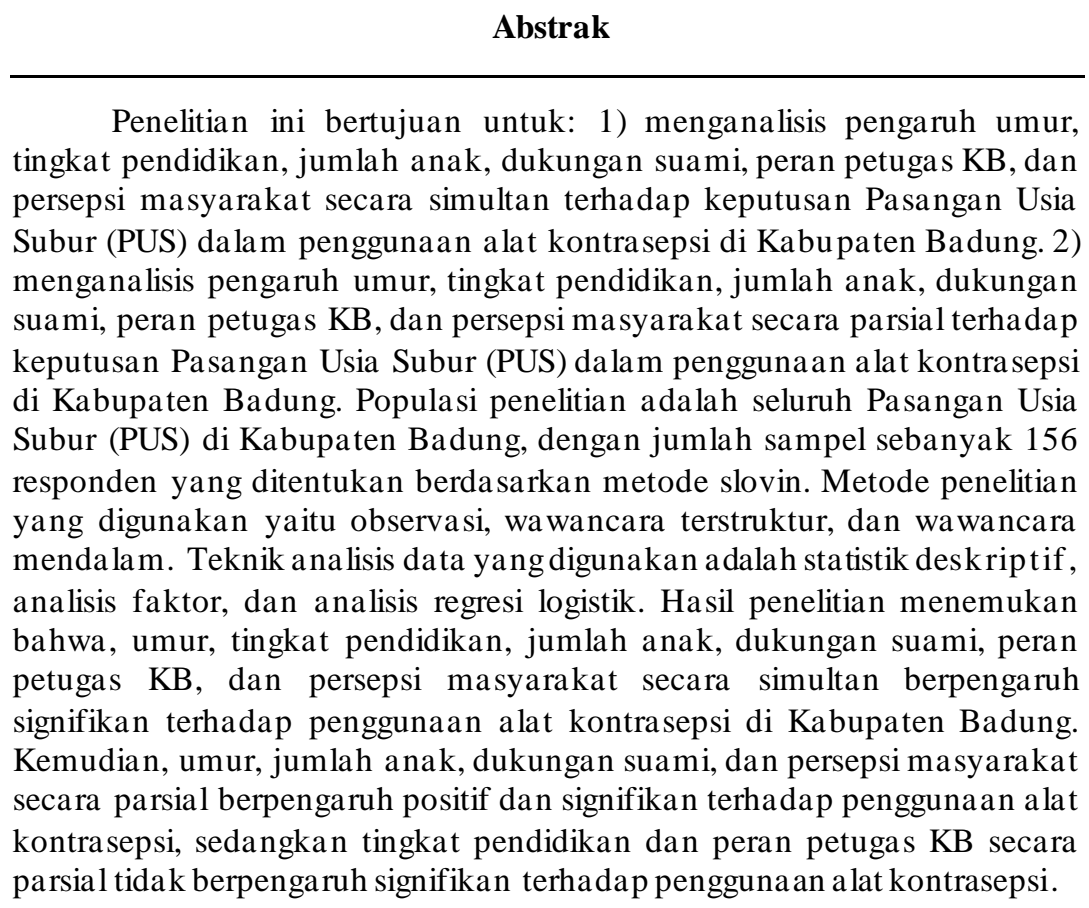




\section{PENDAHULUAN}

Jumlah penduduk Indonesia menduduki posisi ke empat terbesar setelah Cina, In dia, dan Amerika Serikat. Berdasarkan survei penduduk antar Sensus (SUPAS) pada tah un 2019 pend uduk Indonesia mencapai 266,91 juta jiwa. Pemerintah mengupayakan program Keluarga B eren cana bagi Pasangan Usia Subur (PUS) seperti yang terdapat dalam Millenium Development Goals (MDGs) 2015 indikator 5b. Menurut World Health Organization (WHO), Keluarga Berencana (KB) adalah suatu Tindakan dalam membentu individua atau pasangan suami istri untuk: 1) Menghindari kelahiran y ang tidak diinginkan; 2) Memperoleh kelahiran yang diinginkan; 3) Mengatur interval diantara kelah iran' 4) Mengontrol waktu saat kelahiran dalam hubungan dengan umur suami istri; dan 5) Menentukan jumlah anak dalam keluarga.

Penggunaan alat kontrasepsi dalam keluarga berencana di Indonesia menggunakan dua metode, yaitu Metode Kontrasepsi Jangka Panjang (MKJP), dan Non MKJP. Seperti yang dilansir dari BKKBN (2011), MKJP meliputi kontrasepsi uterus (IUD), implan, tubektomi atau disebut juga metode wanita operasi dan vasektomi, juga dikenal sebagai metode bedah pria, dan non -MKJP termasuk suntikan, pil, kondom. Salah satu cara mengatasi permasalahan kependudukan di Indonesia adalah adanya pengambilan keputusan untuk menggunakan alat kontrasepsi. Dalam menyukseskan program keluarga berencana, maka diperlukan adanya peran baik istri maupun suami, salah satu ny a melalui penggunaan alat kontrasepsi. Pada umumnya, pengambilan keputusan dalam menggunakan alat kontrasepsi dipengaruhi oleh karakteristik individu dan keluarga.

Di Indonesia, pendorong utama dari pertumbuhan penduduk masa depan adalah adanya penurunan kesuburan dan norma mengenai ukuran keuarga yang lebih kecil. Meskipun tingkat kesuburan menurun, Indonesia tetap akan mengalami pertumbuhan penduduk yang produktif, karena meskipun wanita sekarang memutuskan memiliki jumlah anak lebih sedikit namun jumlah wanita yang melahirkan cukup besar. Menurut BPS (2013), tingkat pertumbuhan penduduk Indonesia diperkirakan 1,4 persen per tahun pada 2000-2010, dengan asumsi bahwa tingkat penggantian tingkat kesuburan akan tercapai pada tahun 2025, tingkat pertumbuhan penduduk diproyeksikan terus tu run, mencapai 0,6 persen pada tahun 2030-2035, dengan total penduduk sebanyak 305,7 juta. Menurut Adioetomo (2005) dalam Qibthiyyah (2016) dimana ramalan bahwa jendela peluang yang juga dikenal sebagai bonus demografis atau demografis dividen, akan terjadi antara tahun 2020 dan tahun 2030. Setelah periode ini, ketergantungan rasio ini diproyeksikan akan meningkat dan Indonesia akan memasuki fase penuaan penduduk.

Salah sartu prasyarat penggunaan metode kontrasepsi yang tepat adalah pengetahuan mengenai aturan dalam kelahiran dan keluaga berencana $(\mathrm{KB})$. Metode atau cara ko ntrasepsi dibagi dalam dua kategori, yaitu metode kontrasepsi modern dan cara tradisional. Metode kontrasepsi modem meliputi sterilisasi wanita, sterilisasi pria, pil KB, IUD, suntik KB, susuk, kondom pria, intravag, diafragma, kontrasepsi darurat, dan metode amenorrhea laktasi (MAL). Cara tradisional meliputi pantang berkala (sistem kalender), senggama terputus, dan jamu. Pil KB dan suntik KB merupakan metode kontrasepsi yang paling dikenal oleh responden dengan persentase masing-masing sebes ar 98 persen dan 99 persen.

Pada umumnya, kelompok wanita umur 30-34 tahun dan berdomisili di daerah kota memiliki tingkat Pendidikan tinggi dan pengetahuan mengenai metode kontrasepsi. Menurut Kühlbrandt (2019), para professional kesehatan membingkai reproduksi wanita sebagai pertanyaan mengenai pengetahuan, pilihan individu, praktik budaya, atau kombinasi dari hal-hal tersebut, tanpa melihat masalah keuangan karena menurut mereka kontraspepsi diberikan secara gratis kepada wanita.

Berdasakan laporan pendahuluan indicator utama SDKI tahun 2017, diketahui bahwa, terjadi perlambatan penurunan sejak tahun 2002-2003 sampai tahun 2012 di mana selama sepuluh tahun TFR cenderung stagnan. Terjadi peningkatan prevalensi kontrasepsi dari 50 persen pada tahun 1991 menjadi 64 persen pada tahun 2017. Namun, ada perlambatan peningk atan sejak tahun 2002 2003 dimana selama lima belas tahun terakhir penggunaan kontrasepsi modern cenderung stagn an . Dari hal tersebut dapat dilihat bahwa terdapatnya permasalahan yang menyebabkan angka penggunaan

Analisis Faktor yang Mempengaruhi Keputusan Pasangan Usia Suburdalam Penggunaan Alat Kontrasepsi di 
kontrasepsi di Indonesia mengalami perlambatan dan cenderung stagnan selama 15 tahun terakhir, salah satu penyebab terjadinya perlambatan peningkatan pada penggunaan alat kontrasep si tersebut yaitu perubahan sistem pemerintah dari sentralisasi menjadi desentralisasi. Berdasarkan tren pemakaian kontrasepsi pada wanita kawin di Indonesia menurut SDKI tahun 1991-2017 diperoleh informasi bahwa target capaian CPR (Contraceptive Prevalency Rate) hanya mencapai 64 persen. Sebagain besar menggunakan metode kontrasepsi modern (57 persen), dan sisanya menggunakan metode tradisional. KB modern yang digunakan antara lain suktik KB sebesar 29 persen d an pil KB sebesar 12 persen.

Terdapat berbagai faktor yang mendasari keputusan Pasangan Usia Subur (PUS) dalam menggunakan alat kontrasepsi berdasarkan teori perilaku dari Lawrence Green dalam Winarni, E., \& Dawam, M. (2016), perilaku kesehatan termasuk perilaku penggunaan kontrasepsi yang dipengaruhi oleh presdisposisi, faktor pendorong dan pendukung. Faktor presdiposisi adalah terkait dengan karakteristik latar belakang individu dan pengetahuan kontrasepsi. Faktor-faktor penggerak terkait dengan dorongan dari mitra dan tokoh publik, sementara faktor pendukung terkait dengan faktor program, seperti akses dan kualitas keluarga berencana. Informasi, pendidikan dan komunikasi dalam program kontrasepsi, kegiatan keluarga berencana dimana bertujuan untuk meningkatkan pengetahuan, sikap, dan praktik kontrasepsi, mengembangkan keberlanjutan peserta kontrasepsi, kemudian mempertahankan penggunaan kontrasepsi di masyarakat. Beberapa alasan tidak ingin menggunakan alat/cara KB adalah karena tidak mengetahui cara penggunaan, tidak nyaman saat pemakaian, takut akan efek samping yang ditimbulkan, terkait dengan masalah kesehatan, dan perubahan berat badan. Padahal, penggunaan KB turut membantu dalam mengurangi kematian ibu di Indonesia, karena perempuan yang mengatur kehamilan dan kematian akan memiliki resiko lebih lebih kecil.

Penelitian Notoatmojo dalam Setiasih (2016) jika dikaitkan dengan teori perilaku penelitian Lawrence Green (2005) bahwa perilaku dipengaruhi oleh tiga faktor, yaitu faktor yang pertama predisposing factor merupakan faktor pemudah atau mempresuposisikan terjadinya perilaku seseorang yang dapat dilihat dari umur, pendidikan, pengetahuan, sikap, paritas dan riwayat ke sehatan. Faktor yang kedua adalah enabling factor atau faktor pemungkin yaitu faktor yang memungkinkan atau memfasilitasi perilaku atau tindakan, faktor ini meliputi Pelayanan KB (ruangan, alat, dan transportasi). Faktor ketiga adalah reinforcing factor atau faktor penguat yaitu faktor yang memperkuat terjadinya perilaku, dalam hal ini adalah dukungan suami dan dukungan petugas pelayanan KB.

Berdasarkan informasi yang diperoleh dari website Provinsi Bali dalam Angka 2021, diketahui bahwa pada tahun 2016 sampai dengan tahun 2020 jumlah pasangan usia subur di Kabupaten Badung terus mengalami kenaikan. Adanya peningkatan jumlah pasangan usia subur tidak memberikan pengaruh kepada jumlah peseta KB di Kabupaten Badung untuk terus mengalami peningkatan, karena pasangan usia subur yang bukan merupakan akseptor KB berfluktuasi dari tahun ke tahun. Pada tahun 2020 jumlah pasangan usia subur bukan aks eptor KB mengalami penurunan sebesar 0,47 persen, hal ini dikarenakan pada tahun 2020 terdapatnya Pandemi Covid-19 yang menyebabkan masyarakat sebagian besar dirumahkan dan membuat pasan gan u sia subur memilih untuk menggunakan alat kontrasepsi demi mengurangi kemungkinan terjadinya kehamilan yang tidak diinginkan.

Terdapat beberapa variabel yang dapat mempengaruhi keputusan pasangan usia subur dalam menentukan menggunakan alat/cara kontrasepsi atau tidak, seperti tingkat pendidik an berpengaruh terhadap keinginan individu dan pasangan untuk menentukan jumlah anak. Bongaarts dan Judith (1996) dalam Saskara \& Marhaeni (2015) mengatakan bahwa wanita yang berpendidikan menginginkan lebih sedikit anak agar memiliki pendapatan lebih tinggi dan lebih bis a berinvestasi dalam nutrisi dan pendidikan anak. Gustavo (2005) dalam Saskara \& Marhaeni (2015) men yatakan pendidikan tinggi dapat menjadi cara mengendalikan fertilitas.

Handayani \& Rahmawati (2016) dalam penelitiannya menemukan bahwa keikutsertaan KB pada pasangan usia subur dipengaruhi oleh faktor pengetahuan, Pendidikan, agama, jumlah anak,

Analisis Faktor yang Mempengaruhi Keputusan Pasangan Usia Suburdalam Penggunaan Alat Kontrasepsidi 
sosial ekonomi, serta dukungan pasangan dan keluarga. Periode umur tertentu dapat men yebabkan perbedaan pada kontrasepsi yang dibutuhkan. Dengan bertambahnya umur maka peluang dalam menggunakan alat kontrasepsi akan semakin tinggi. Selain itu, dukungan suami sangat dibutuhkan pula dalam menjalankan program Keluarga Berencana. Dukungan suami sangat berpen garuh besar dalam pengambilan keputusan menggunakan atau tidaknya wanita usia subur untuk menggunakan alat kontrasepsi. Petugas kesehatan (Petugas KB) merupakan pihak yang mengambil peran dalam tahap akhir pemakaian alat kontrasepsi calon akseptor keluarga berencana. Persepsi masyarakat terhadap program keluarga juga merupakan suatu faktor penting yang mempengaruhi keputusan pasangan u sia subur dalam menggunakan alat kontrasepsi karena persepsi masyarakat akan su atu hal merupakan landasan bagi timbulnya kesediaan untuk ikut terlibat dan berperan aktif. Makna positif atau negatif sebagai hasil persepsi akan menjadi pendorong atau penghambat jalannya suatu kegiatan.

Dalam penelitian Triyanto \& Indriani (2018) bahwa bertambahnya umur tentu peluang responden untuk menggunakan alat kontrasepsi akan semakin tinggi. Menurut Rotie, dkk (2015) dalam penelitiannya didapatkan hasil bahwa pendidikan mempengaruhi penggun aan kontrasepsi. Semakin tinggi pendidikan seseorang maka semakin mudah dalam menerima informasi sehingga banyak pula pengetahuan yang dimilikinya. Muatiarawati (2014) menemukan bahwa terdapat hubungan antara jumlah anak dengan penggunaan alat kontrasepsi, terutama ibu yang sudah memiliki tiga anak atau lebih.

Dalam penelitian Zuhriyah, dkk (2017) bahwa adanya penyuluhan Petugas $\mathrm{KB}$ mengenai $\mathrm{KB}$ yang intensif mempengaruhi keputusan pasangan usia subur dalam penggunaan alat kontrasepsi. Menurut Okfi Nurhanifah (2017) dalam penelitiannya menyatakan bahwa persepsi masyarakat memiliki hubungan yang positif dan signifikan dengan penggunaan alat kontrasepsi. Nuryati \& Fitria (2014), mengungkapkan ada hubungan yang bermakna antara dukungan suami dengan pemilihan alat kontrasepsi. Dalam penelitian Tampubolon dan Tarigan (2018) terdapat hubungan yang signifikan antara pengetahuan, dukungan suami dan dukungan petugas kesehatan dengan penggunaan kontrasepsi.

Berdasarkan penjelasan dan penelitian-penelitian sebelumnya, dapat dirumuskan dua hipotesis penelitian sebagai berikut: $\mathrm{H}_{1}$ : Umur, tingkat pendidikan, jumlah anak, du kungan suami, peran petugas KB, dan persepsi masyarakat secara simultan berpengaruh terhadap keputusan Pasangan Usia Subur (PUS) dalam penggunaan alat kontrasepsi di Kabupaten Badung. $\mathrm{H}_{2}$ : Umur, tingkat pendidikan, jumlah anak, dukungan suami, peran petugas $\mathrm{KB}$, dan persepsi masyarakat secara parsial berpengaruh positif terhadap keputusan Pasangan Usia Subur (PUS) dalam penggunaan alat kontrasepsi di Kabupaten Badung.

\section{METODE PENELITIAN}

Penelitian ini mengembangkan dan menguji teori dengan menggunakan analisis regresi logistik untuk menganalisis pengaruh simultan dan parsial pada variabel bebas (independen variable) yaitu umur, tingkat pendidikan, jumlah anak, dukungan suami, peran petugas $\mathrm{KB}$, $\mathrm{d}$ an persepsi masyarakat khususnya pasangan usia subur terhadap variabel terikat (dependent variable) yaitu penggunaan alat kontrasepsi di Kabupaten Badung. Lokasi penelitian dilakukan di Kabupaten Badung. Alasan pemilihan lokasi ini dikarenakan laju pertumbuhan penduduk di Kabupaten Badung pada tahun 2000-2010 merupakan laju pertumbuhan penduduk tertinggi di Provinsi Bali yaitu sebesar 4,62 persen. Populasi pada penelitian ini adalah pasangan usia subur yang terdapat di Kabupaten Badung yaitu sebanyak 72.386 orang. Dengan menggunakan rumus Slovin, populasi sebanyak 44.175 orang pasangan usia subur yang tinggal di tiga kecamatan di Kabupaten Badung tersebut dan dengan batas ketelitian 8 persen, didapatkan sampel sebanyak 156 orang yang dimana terbagi me njadi 123 orang yang menggunakan KB dan 33 orang yang tidak menggunakan KB. Jenis data yang digunakan dalam penelitian ini adalah data kuantitatif.

Analisis Faktor yang Mempengaruhi Keputusan Pasangan Usia Suburdalam Penggunaan Alat Kontrasepsidi 
Metode penentuan sampel dalam penelitian ini yaitu dengan metode Purposive Sampling yang dikombinasikan dengan Accidental Sampling. Metode pengumpulan data yang digunakan adalah observasi, wawancara terstruktur, dan wawancara mendalam. Instrumen penelitian digunak an oleh peneliti pada saat pengumpulan data meliputi kuesioner, pedoman wawancara, dan check list. Selanjutnya, kuesioner mengenai data persepsi akan dikumpulkan dengan skala likert. Dilakukan dua pengujian terhadap instrumen yang digunakan yaitu pengujian validitas d an pengujian reliabilitas. Sebelum melakukan analisis data menggunakan analisis binary logistik, diperlukannya analisis faktor pada variabel kelima yaitu variabel peran petugas KB untuk menkonfirmasi data tersebut telah mencerminkan peran petugas KB serta mendapatkan skor faktor yang nantinya akan digun ak an pada analisis data regresi binary logistic. Terdapat dua cara yang dapat dipergun akan dalam melakukan analisis faktor khususnya koefisien skor faktor, yaitu Principal Component Analysis (PCA) dan Common Factor Analysis (CFA). Pada analisis faktor dilakukan beberapa tahapan diantaranya: KMO and Bartlett's test, Anti-image Matrices, Communalities, dan Total Variance Explained. Teknik analisis data yang digunakan dalam penelitian ini adalah teknik analisis regresi logistik.

\section{HASIL DAN PEMBAHASAN}

Berdasarkan hasil pengujian validitas pada Tabel 1 dapat dilihat bahwa pada indikator proses sosialisasi nilai korelasi $(0,856)>0,30$. Pada indikator cara penyampaian dari petugas KB nilai korelasi $(0,878)>0,30$. Pada indikator layanan konseling saat berkonsultasi nilai korelasi $(0,874)>$ 0,30 . Seluruh nilai korelasi pada ketiga indikator $>0,30$ dan nilai signifikansi $<0,05$ artin ya, selu ruh indikator yang digunakan untuk mengukur variabel peran petugas KB dapat dik atakan valid. Data valid adalah data yang tidak berbeda antara data yang dilaporkan oleh peneliti dengan data yang sesungguhnya terjadi pada objek penelitian (Sugiyono, 2014).

Tabel 1.

Hasil Pengujian Validitas Terhadap Indikator Variabel Peran Petugas KB

\begin{tabular}{clcccc}
\hline No & \multicolumn{1}{c}{ Indikator } & $\begin{array}{c}\text { Item } \\
\text { Pernyataan }\end{array}$ & $\begin{array}{c}\text { Koefisien } \\
\text { Korelasi }\end{array}$ & $\begin{array}{c}\text { Signifikansi } \\
\text { Pertanyaan }\end{array}$ & Keterangan \\
\hline 1 & Proses Sosialisasi & $\mathrm{X}_{5.1}$ & 0,856 & 0,000 & Valid \\
\hline 2 & $\begin{array}{l}\text { Cara Penyampaian dari } \\
\text { Petugas KB }\end{array}$ & $\mathrm{X}_{5.2}$ & 0,878 & 0,000 & Valid \\
\hline 3 & $\begin{array}{l}\text { Layanan Konseling Saat } \\
\text { Berkonsultasi }\end{array}$ & $\mathrm{X}_{5.3}$ & 0,874 & 0,000 & Valid \\
\hline
\end{tabular}

Sumber : Data diolah, 2021

Tabel 2.

Hasil Pengujian Reliabilitas Terhadap Indikator Variabel Peran Petugas KB

\begin{tabular}{c|c}
\hline Cronbach's Alpha & Keterangan \\
\hline, 848 & Reliabel \\
\hline
\end{tabular}

Sumber: Data diolah, 2021

Dari Tabel 2 dapat dilihat bahwa nilai cronbach alpha dari ketiga indikator tersebut $(0,848)$ $>$ nilai minimal cronbach alpha $(0,60)$. Artinya, pernyataan pada kuesioner tersebut memiliki tingkat reliabilitas yang baik dan layak dipakai untuk mengumpulkan data dalam pengujian hipotesis.

Berdasarkan Pekerjaan, dimana status pekerjaan dapat berpengaruh terhadap keik uts erta an dalam Keluarga Berencana (KB) karena adanya faktor pengaruh lingkungan pekerjaan yang

Analisis Faktor yang Mempengaruhi Keputusan Pasangan Usia Suburdalam Penggunaan Alat Kontrasepsi di 
mendorong seseorang untuk ikut dalam KB, sehingga secara tidak langsung akan mempengaruhi status dalam pemakaian kontrasepsi (Siregar, 2010 dalam Kadir 2013). Berdasarkan hasil pen elitian diketahui bahwa dari 156 reponden mengenai keputusan dalam penggunaan alat kontrasepsi di Kabupaten Badung, proporsi berdasarkan pekerjaan ini dapat dibagi menjadi 5 kategori diantarany a yaitu pegawai swasta, ibu rumah tangga, wiraswasta, PNS, dan lainnya. Kategori lainnya disin i yaitu responden yang memiliki pekerjaan sebagai pedagang, apoteker, pegawai puskesmas, penjahit, pegawai kontrak, tukang sapu, buruh lepas harian, pegawai tata usaha, kepala kasir, dan house keeping. Mayoritas pengguna alat kontrasepsi merupakan ibu rumah tangga dan untuk bukan pengguna alat kontrasepsi mayoritas adalah pegawai swasta. Hal ini dikarenakan responden penggu na KB yang merupakan ibu rumah tangga tentunya lebih sering berada di ru mah memiliki intensitas lebih tinggi untuk bertemu dengan suami, maka dari itu responden menggunakan alat kontrasepsi untuk menghindari kehamilan yang tidak diinginkan. Sebaliknya, responden yang bukan pengguna KB merupakan pegawai swasta memilih tidak menggunakan alat kontrasepsi selain karena memiliki kesibukan yang berbeda dengan suami juga lebih siap secara finansial apabila terjadi kehamilan y ang tidak terduga. Nilai minimum pada pengguna KB dan bukan pengguna KB yaitu sebesar 1,00 atau berada pada Pegawai Swasta, kemudian untuk nilai maksimum pada pengguna KB dan bukan Pengguna KB yaitu sebesar 5,00 atau berada pada pekerjaan lainnya seperti pedagang, apoteker, pegawai puskesmas, penjahit, pegawai kontrak, tukang sapu, buruh lepas harian, pegawai tata usaha, kepala kasir, dan house keeping. Nilai rata-rata untuk pengguna KB yaitu sebesar 2,2276, kemudian nilai rata-rata untuk bukan pengguna KB yaitu sebesar 2,0606. Nilai standard deviasi untuk pengguna KB yaitu sebesar 1,18607 dan untuk bukan pengguna KB yaitu sebesar 1,27237.

Berdasarkan hasil penelitian diketahui bahwa diantara 6 kelompok umur responden yang dikelompokkan dalam rentang umur 5 tahun, kelompok umur yang mendominasi sebagai pengguna alat kontrasepsi yaitu kelompok umur 35-39 tahun dengan persentase sebesar 24,4 persen, sed an gkan untuk responden bukan pengguna alat kontrasepsi yaitu kelompok umur 25-29 tahun dengan persentase sebesar 36,4 persen. Kelompok umur responden yang paling sedikit untuk penggun a KB dan bukan pengguna KB yaitu pada kelompok umur 47-49 tahun yaitu sebesar 3,3 persen, sed an gkan tidak ada responden bukan pengguna alat kontrasepsi pada kelompok umur tersebut. Hal ini dikarenakan sebagian besar masyarakat dengan kelompok umur 25-29 tahun biasanya tidak menggunakan alat kontrasepsi dikarenakan sedang menginginkan anak segera atau masih menginginkan anak lagi, sedangkan pada kelompok umur 35-39 tahun dengan persen tase tertinggi yang memilih untuk menggunakan alat kontrasepsi yaitu dikarenakan masyarakat pada umur lebih dari 35 tahun umumnya telah memiliki satu orang anak, maka dari itu responden memilih menggunakan alat kontrasepsi untuk menunda kelahiran atau tidak menginginkan kehamilan lagi. Nilai minimu m pada pengguna KB dan bukan pengguna KB yaitu sebesar 1,00 atau berada pada umu r 20 - 24 tahun, kemudian untuk nilai maksimum pada pengguna KB yaitu sebesar 6,00 atau berada pada umur 45-49 tahun dan untuk bukan Pengguna KB yaitu sebesar 5,00 atau berada pada u mur 40-44 tahun. Nilai rata-rata untuk pengguna $\mathrm{KB}$ yaitu sebesar 3,6911, kemudian nilai rata-rata untuk bukan pengguna $\mathrm{KB}$ yaitu sebesar 2,6061. Nilai standard deviasi untuk pengguna KB yaitu sebesar 1,39160 dan untuk bukan pengguna KB yaitu sebesar 1,24848. Hasil penelitian ini juga diperkuat dengan wawancara yang dilakukan pada Ibu Anisa berusia 25 tahun yang beralamat di Kelurahan Ungasan, Kuta Selatan pada tanggal 20 Februari 2021 yang berpendapat bahwa :

"Saya dan suami baru melangsungkan pernikahan setahun yang lalu dan belum dikaruniai seorang anak, maka dari itu saya dan suami sepakat untuk tidak menggunakan alat kontrasepsi agar lebih mudah untuk berkemungkinan memiliki anak".

Berdasarkan hasil penelitian diketahui bahwa responden pengguna KB dengan persentase terbanyak yaitu pada tingkat pendidikan tamat SMA dengan persentase sebesar 43,1 persen, sedangkan untuk responden bukan pengguna KB dengan persentase terb any ak yaitu pada tingkat pendidikan Diploma I/II/III/Sarjana yaitu sebesar 51,5 persen. Hal ini berarti baik pengguna KB maupun bukan pengguna KB telah memiliki bekal pendidikan serta pengetahuan yan g baik secara

Analisis Faktor yang Mempengaruhi Keputusan Pasangan Usia Suburdalam Penggunaan Alat Kontrasepsi di 
umum terkait program keluarga berencana. Nilai minimum pada pengguna KB yaitu sebesar 1,00 atau berada pada tingkat pendidikan tidak tamat $\mathrm{SD}$, sedangkan nilai minimum pada bukan pengguna $\mathrm{KB}$ yaitu sebesar 5,00 atau berada pada tingkat pendidikan tamat SMA. Nilai maksimum pada pengguna KB dan bukan Pengguna KB yaitu sebesar 6,00 atau berada pada tingkat pendidikan Diploma I/II/III/Sarjana. Nilai rata-rata untuk pengguna KB yaitu sebesar 5,0650, kemudian nilai rata-rata untuk bukan pengguna KB yaitu sebesar 5,5152. Nilai standard deviasi untuk penggu na KB yaitu sebesar 1,06155 dan untuk bukan pengguna KB yaitu sebesar 0,50752.

Berdasarkan hasil penelitian diketahui bahwa mayoritas responden pengguna KB dan bukan pengguna KB saat ini telah memiliki dua orang anak dan anak yang diinginkan yaitu mayoritas menginginkan dua orang anak. Hal tersebut berarti program yang telah dibuat oleh pemerintah mengenai dua anak cukup sudah terdengar di masyarakat, namun untuk beberap a masyarakat yang memilih memiliki anak lebih dari dua orang biasanya masih terikat dengan memiliki anak sesuai dengan urutan nama di Bali yaitu Putu, Kadek, Komang, Ketut atau yang sering disebut dengan 'KB Bali'. Namun, beberapa orang memilih untuk memiliki anak lebih dari dua orang juga biasanya dikarenakan belum memiliki anak laki-laki. Nilai minimum pada pengguna KB yaitu sebesar 1,00 atau berarti belum memiliki anak dan hanya menginginkan satu orang anak saja, se dangkan pada bukan pengguna KB yaitu sebesar 1,00 untuk jumlah anak hidup dan 2,00 untuk jumlah anak yang diinginkan atau bukan pengguna $\mathrm{KB}$ belum memilii anak dan menginginkan dua orang anak, kemudian untuk nilai maksimum pada pengguna KB yaitu sebesar 5,00 untuk jumlah anak hidup dan 4,00 untuk jumlah anak yang diinginkan atau sudah memiliki empat anak dan hany a mengingin kan empat anak, sedangkan untuk bukan Pengguna KB yaitu sebesar 5,00 atau berada pada umur 42-46 tahun. Nilai rata-rata untuk pengguna KB dengan jumlah anak hidup yaitu sebesar 3,2520 dan un tuk jumlah anak yang diinginkan yaitu sebesar 2,5610, sedangkan nilai rata-rata untuk bukan pen ggu na KB dengan jumlah anak hidup yaitu sebesar 2,5152 dan untuk jumlah anak y ang diin gink an yaitu sebesar 2,4848. Nilai standard deviasi untuk pengguna KB dengan jumlah anak hid up yaitu sebesar 1,02903 dan untuk jumlah anak yang diinginkan yatu sebesar 0,84102 , sedangkan untuk bukan pengguna KB yaitu sebesar 1,18466 dan bukan pengguna KB dengan jumlah anak hidup yaitu sebesar 1,06423 dan untuk jumlah anak yang diinginkan yaitu sebesar 0,75503 . Hal ini diperkuat dengan wawancara yang dilakukan pada Ibu Komang Marini berusia 39 tahun yang beralamat di Kelurahan Benoa, Kecamatan Kuta Selatan pada tanggal 6 Maret 2021 yang berpendapat bahwa :

"Saat ini saya sudah memiliki anak sebanyak empat orang, namun keempat anak saya berjenis kelamin perempuan. Saya dan suami masih menginginkan anak laki-laki supaya ada yang menggantikan kami untuk menyama braya di lingkungan ini, karena seperti yang kita ketahui bahwa anak perempuan cenderung untuk menikah ke luar dan akan tinggal dengan keluarga suaminya. Maka dari tu, saya dan suami masih berusaha untuk memiliki anak laki-laki".

Berdasarkan hasil penelitian diketahui bahwa mayoritas responden mendapat dukungan dari suaminya terkait keputusan akan menggunakan atau tidak menggunakan alat kontrasepsi, namun ada pula responden yang diberikan keputusan sepenuhnya oleh sang suami terkait akan menggunakan alat kontrasepsi atau tidak. Dapat dilihat bahwa responden pengguna KB mendapat dukungan suami sebanyak $95,1 \%$, sedangkan bagi responden bukan pengguna KB mendapat dukungan suami sebanyak 69,7\% dan 30,3\% diantaranya tidak mendapat dukungan suami atau diberikan keputusan sepenuhnya kepada pihak responden. Nilai minimum pada pengguna KB dan bukan pengguna KB yaitu sebesar 1,00 atau berada pada tidak mendapatkan dukungan dari suami. Nilai maksimum pada penggun a KB dan bukan Pengguna KB yaitu sebesar 2,00 atau berada pada mendapat dukungan dari suami. Nilai standard deviasi untuk pengguna KB yaitu sebesar 0,21629 dan untuk bukan penggun a KB yaitu sebesar 0,46669. Hal ini berkaitan dengan wawancara yang dilakukan pada Ibu Wayan Suastri berusia 42 tahun yang beralamat di Kelurahan Benoa, Kecamatan Kuta Selatan pada tan ggal 6 Maret 2021 yang berpendapat bahwa :

Analisis Faktor yang Mempengaruhi Keputusan Pasangan Usia Suburdalam Penggunaan Alat Kontrasepsidi 
"Keputusan saya untuk menggunakan alat kontrasepsi tidak lepas dari dukungan suami saya, dikarenakan sebelumnya saya sempat meng gunakan alat kontrasepsi spiral selama sekitar 2 tahun namun saya dan suami mendapat keluhan bahwa saat melakukan hubungan suami istri, saya dan suami merasa kurang nyaman dan saya merasakan sedikit sakit karena adanya alat tertanam di alat vital saya. Maka dari itu suami memberikan saran untuk melepas alat kontrasepsi tersebut dan beralih ke alat kontrasepsi kondom saja”.

Berdasarkan hasil penelitian diketahui bahwa responden pengguna KB dan bukan penggun a KB sebagian besar memilih kategori setuju untuk proses sosialisasi, cara penyampaian, dan layanan konseling yang diberikan oleh petugas KB. Hal tersebut menunjukkan bahwa program keluarga berencana ini masih terdengar diantara masyarakat dan petugas KB masih tetap melakukan sosialisasi kepada masyarakat terkait program keluarga berencana ini. Namun, pada responden pengguna KB dan bukan pengguna KB terdapat beberapa responden yang memilih kategori tidak setuju pada pertanyaan terkait proses sosialisasi dari petugas $\mathrm{KB}$ tersebut, hal ini dikarenakan responden tersebut jarang bahkan terdapat pula beberapa responden yang hampir tidak pernah mengikuti acara-acara yang dilakukan di lingkungan tempat tinggal mereka utamanya untuk sosialisasi. Maka dari itu, masyarakat tersebut tidak mengetahui seperti apa proses sosialisasi yang diberikan petugas KB di lapangan.

Berdasarkan hasil penelitian diketahui bahwa mayoritas responden pengguna KB dan bukan pengguna KB memilih angka lima yang artinya alat kontrasepsi sangat bermanfaat bagi keluarga. Namun, dapat dilihat pada responden bukan pengguna KB memilih angka yang cenderung beragam. Hal ini dikarenakan bagi responden yang tidak menggunakan KB merasa bahwa alat kontrasepsi kurang bermanfaat bagi keluarga karena merasa tanpa menggunakan KB masih bisa menjarangkan kehamilan atau menunda kelahiran anak. Nilai minimum pada pengguna KB yaitu sebe sar 3,00 atau persepsi masyarakat pengguna KB terhadap manfaat program keluarga berencana berada pad a angka tiga, sedangkan nilai minimum pada bukan pengguna KB yaitu sebesar 1,00 atau persepsi masyarakat bukan pengguna $\mathrm{KB}$ terhadap manfaat program keluarga berencana yaitu pada angka satu. Nilai maksimum pada pengguna KB dan bukan Pengguna KB yaitu sebesar 5,00 atau persepsi masyarakat pengguna KB dan bukan pengguna KB terhadap manfaat program keluarga berencan a berada pad a angka lima. Nilai rata-rata untuk pengguna $\mathrm{KB}$ yaitu sebesar 4,6585, kemudian nilai rata-rata un tuk bukan pengguna KB yaitu sebesar 3,6667. Nilai standard deviasi untuk penggu na KB yaitu sebesar 0,50269 dan untuk bukan pengguna KB yaitu sebesar 1,40683.

Tabel 3.

Kaiser Meyer Olkin and Bartlett's Test

\begin{tabular}{llr}
\hline Kaiser-Meyer-Olkin Measure of Sampling Adequacy. &, 663 \\
\hline Bartlett's Test of Sphericity & Approx. Chi-Square & 262,023 \\
\cline { 2 - 3 } & $\mathrm{df}$ & 3 \\
\cline { 2 - 3 } & Sig. &, 000 \\
\hline
\end{tabular}

Sumber: Data diolah, 2021

Berdasarkan hasil pengujiam diperoleh nilai Kaiser Meyer Olkin Measure of Sampling Adequance sebesar 0,663 > 0,50 dan nilai Bartlett's TestfSphericity (Sig.) 0,00 <0,50, maka analisis faktor dalam penelitian ini dapat dianjutkan karena sudah memenuhi syarat pertama.

Dari Tabel 4, terdapat kode (a) yang artinya tanda untuk Measure of Sampling Adequancy (MSA). Diketahui nilai MSA dari masing-masing yang diteliti adalah sebagai berikut : Proses sosialisasi sebesar 0,887; Cara penyampaian dari petugas KB sebesar 0,620; Layanan konseling saat berkonsultasi sebesar 0,611. Persyaratan yang harus terpenuhi dalam analisis faktor adalah nilai MSA $>0,50$, maka persyaratan kedua dalam analisi faktor ini terpenuhi.

Analisis Faktor yang Mempengaruhi Keputusan Pasangan Usia Suburdalam Penggunaan Alat Kontrasepsi di 
Tabel 4.

Anti-image Matrices

\begin{tabular}{|c|c|c|c|c|}
\hline & & $\begin{array}{c}\text { Proses } \\
\text { Sosialisasi } \\
\end{array}$ & $\begin{array}{c}\text { Cara Penyampaian } \\
\text { dari Petugas KB }\end{array}$ & $\begin{array}{c}\text { Layanan } \\
\text { Konseling Saat } \\
\text { Berkonsultasi } \\
\end{array}$ \\
\hline \multirow{3}{*}{$\begin{array}{l}\text { Anti-image } \\
\text { Covariance }\end{array}$} & Proses Sosialisasi &, 653 &,- 058 &,- 102 \\
\hline & Cara Penyampaian dariPetugas &,- 058 &, 271 &,- 207 \\
\hline & Layanan Konseling Saat Berkonsultasi &,- 102 &,- 207 &, 260 \\
\hline \multirow{3}{*}{$\begin{array}{l}\text { Anti-image } \\
\text { Correlation }\end{array}$} & Proses Sosialisasi &, $887^{\mathrm{a}}$ &,- 139 &,- 249 \\
\hline & Cara Penyampaian dari Petugas KB &,- 139 &, $620^{\mathrm{a}}$ &,- 781 \\
\hline & Layanan Konseling Saat Berkonsultasi &,- 249 &,- 781 &, $611^{\mathrm{a}}$ \\
\hline
\end{tabular}

a. Measures of Sampling Adequacy(MSA)

Sumber: Data diolah, 2021

Tabel 5.

Communalities

\begin{tabular}{lrr}
\hline & Initial & Extraction \\
\hline Proses Sosialisasi & 1,000 &, 617 \\
\hline Cara Penyampaian dari Petugas & 1,000 &, 847 \\
\hline Layanan Konseling Saat Berkonsultasi & 1,000 &, 865 \\
\hline
\end{tabular}

Extraction Method: Principal Component Analysis.

Sumber: Data diolah, 2021

Tabel 5 ini menunjukkan ketiga indikator yang diteliti dapat menjelaskan faktor atau tid ak. Variabel dianggap mampu menjelaskan faktor jika nilai Extarction lebih besar dari 0,50. Dapat dilih at pada tabel bahwa seluruh indikator memiliki angka Extraction lebih besar dari 0,50, maka dapat dikatakan bahwa semua variabel dapat dipakai untuk menjelaskan faktor.

Tabel 6.

Total Variance Explained

\begin{tabular}{ccccccc}
\hline & \multicolumn{3}{c}{ Initial Eigenvalues } & \multicolumn{2}{c}{ Extraction Sums of Squared Loadings } \\
\cline { 2 - 6 } Component & Total & \% of Variance & Cumulative \% & Total & \% of Variance & Cumulative \% \\
\hline 1 & 2,330 & 77,657 & 77,657 & 2,330 & 77,657 & 77,657 \\
\hline 2 &, 522 & 17,384 & 95,042 & & \\
\hline 3 & 149 & 4,958 & 100,000 & & \\
\hline
\end{tabular}

Extraction Method: Principal Component Analysis.

Sumber: Data diolah, 2021

Tabel 6 merupakan tabel total variance explained yang menunjukkan nilai dari masingmasing variabel. Dalam penelitian ini terdapat tiga variabel berarti ada tiga komponen yang di analisis, didapatkan hasil bahwa nilai total variance explained sebesar 77,657 persen > 60 persen.

Tabel 7.

Hasil Pengujian Hosmer and Lemeshow's Goodness of Fit Test

Hosmer and Lesemshow Test

\begin{tabular}{cccc}
\hline Step & Chi-square & df & Sig. \\
\hline 1 & 12,522 & 8 &, 129 \\
\hline
\end{tabular}

Sumber: Data diolah, 2021

Analisis Faktor yang Mempengaruhi Keputusan Pasangan Usia Subur dalam Penggunaan Alat Kontrasepsi di 
Chi Square Hosmer and Lemeshow hitung sebesar 12,522 $<$ Nilai Chi Square tabel $_{(\mathrm{DF}}=7, \alpha=$ ${ }_{0,05)}$ adalah sebesar 15,507 atau nilai signifikansi sebesar 0,129 >0,05, sehigga pengujian Hosmer and Lemeshow menerima $\mathrm{H}_{0}$ yang menunjukkan bahwa model dapat diterima dan pen gujian hipotesis dapat dilakukan sebab tidak adanya perbedaan yang signifikan antara model dengan nilai observasinya dan model penelitian ini dapat dinyatakan fit. Maka dari itu model regresi logistik y ang digunakan sudah dapat menjelaskan data dan dapat digunakan untuk analisis selanjutnya.

Tabel 8.

Hasil Pengujian Overall Model Fit

-2 log likelihood

\begin{tabular}{|c|c|c|c|c|c|}
\hline \multicolumn{3}{|c|}{ Block Number $=0$} & \multicolumn{3}{|c|}{ Block Number $=1$} \\
\hline \multirow[t]{6}{*}{ Step 0} & 1 & 161,691 & Step 1 & 1 & 119,780 \\
\hline & 2 & 160,989 & & 2 & 108,570 \\
\hline & 3 & 160,988 & & 3 & 106,873 \\
\hline & 4 & 160,988 & & 4 & 106,806 \\
\hline & & & & 5 & 106,806 \\
\hline & & & & 6 & 106,806 \\
\hline
\end{tabular}

Sumber: Data diolah, 2021

Hasil pengujian dari keseluruhan model (Overall Model Fit) pada Tabel 8 menu njukkan bahwa angka $-2 \log$ likelihood pada awal (block number $=0$ ) dan -2 log likelihood pada block number $=1$ mengalami penurunan atau nilai $-2 \log \operatorname{Likehood}($ Block Number $=0)$ sebesar 160,98 $8>$ nilai -2 Log Likehood (Block Number =1) sebesar 106,806, hal tersebut menunjuk kan model regresi y ang baik.

Berdasarkan hasil pengujian menggunakan nagelkerke $R$ square adalah sebesar 0,456 atau 45,6 persen, artinya keputusan Pasangan Usia Subur (PUS) dalam penggu naan alat kontrase psi di Kabupaten Badung dapat dipengaruhi secara signifikan oleh variabel umur, tingkat pendidikan, jumlah anak, dukungan suami, peran petugas KB, dan persepsi masyarakat sebesar 45,6 persen dan sisanya sebesar 54,4 persen dipengaruhi oleh variabel lain diluar model penelitian.

Tabel 9.

Hasil Pengujian Pengaruh Umur, Tingkat Pendidikan, Jumlah Anak, Dukungan Suami, Petugas KB, dan Persepsi Masyarakat Secara Simultan Terhadap Penggunaan Alat Kontrasepsi

\begin{tabular}{ccccc}
\multicolumn{5}{c}{ Omnibus Test of Model Coefficients } \\
\hline \multirow{3}{*}{ Step 1 } & Chi-square & df & Sig. \\
& Step & 54,182 & 6 &, 000 \\
& Block & 54,182 & 6 &, 000 \\
& Model & 54,182 & 6 &, 000 \\
\hline
\end{tabular}

Sumber: Data diolah, 2021

Hasil pengujian hipotesis secara simultan dengan menggunakan Omnibus Test menunjukkan bahwa nilai chi square $(54,182)>$ chi square tabel $\mathrm{l}_{(\mathrm{DF}=6, \alpha=0,05)}(12,592)$, atau nilai sig pada hasil omnibus test of model coefficients $(0,000)<0,05$ sehingga variabel umur, tingkat pendidikan, ju mlah anak, dukungan suami, peran petugas $\mathrm{KB}$, dan persepsi masyarakat memberikan pengaruh nyata terhadap model atau model dapat dinyatakan fit. Hal ini menunjukkan bahwa variabel umur, tingkat pendidikan, jumlah anak, dukungan suami, peran petugas $\mathrm{KB}$, dan persepsi masyarakat secara simultan berpengaruh signifikan terhadap keputusan Pasangan Usia Subur (PUS) dalam penggun aan alat kontrasepsi.

Hal ini sesuai dengan hasil penelitian Magetin (2016) dalam Luky dan Diah (2018), menunjukkan bahwa umur istri, jumlah anak dan tingkat pendidikan memiliki hubungan yang signifikan dengan penggunaan alat kontrasepsi serta dalam penelitian Tampubolon dan Tarigan (2018) Analisis Faktor yang Mempengaruhi Keputusan Pasangan Usia Suburdalam Penggunaan Alat Kontrasepsi di 
yang menyatakan bahwa terdapat hubungan yang signifikan antara pengetahuan, dukungan suami dan dukungan petugas kesehatan dengan penggunaan kontrasepsi. Hasil penelitian ini didukung juga oleh penelitian dari Afnita (2015) yang menyatakan bahwa terdapat hubungan yang signifikan antara persepsi dengan partisipasi aktif dalam penggunaan kontrasepsi.

Tabel 10.

Hasil Pengujian Pengaruh Umur, Tingkat Pendidikan, Jumlah Anak, Dukungan Suami, Petugas KB, dan Persepsi Masyarakat Secara Parsial Terhadap Penggunaan Alat Kontrasepsi

\begin{tabular}{|c|c|c|c|c|c|c|c|c|c|}
\hline & & \multirow[b]{2}{*}{ B } & \multirow[b]{2}{*}{ S.E. } & \multirow[b]{2}{*}{ Wald } & \multirow[b]{2}{*}{ df } & \multirow[b]{2}{*}{ Sig. } & \multirow[b]{2}{*}{$\operatorname{Exp}(B)$} & \multicolumn{2}{|c|}{$\begin{array}{c}95 \% \text { C.I.for } \\
\operatorname{EXP}(\mathbf{B})\end{array}$} \\
\hline & & & & & & & & Lower & Upper \\
\hline \multirow[t]{7}{*}{ Step $1^{\mathrm{a}}$} & Umur & ,102 & ,043 & 5,667 & 1 & ,017 & 1,107 & 1,018 & 1,205 \\
\hline & Tingkat Pendidikan &,- 200 & 118 & 2,873 & 1 &, 090 &, 819 &, 650 & 1,032 \\
\hline & Jumlah Anak Hidup & ,757 & ,270 & 7,875 & 1 &, 005 & 2,132 & 1,256 & 3,618 \\
\hline & Dukungan Suami & 1,603 & 667 & 5,776 & 1 & ,016 & 4,968 & 1,344 & 18,361 \\
\hline & Peran Petugas KB &,- 253 & ,238 & 1,132 & 1 & 287 &, 776 &, 487 & 1,238 \\
\hline & Persepsi Masyarakat &, 803 & ,267 & 9,080 & 1 & 019 & 2,233 & 1,324 & 3,765 \\
\hline & Constant & $-5,578$ & 2,385 & 5,471 & 1 & ,019 & ,004 & & \\
\hline
\end{tabular}

a. Variable(s) entered on step 1: Umur, Tingkat Pendidikan, Jumlah Anak Hidup, Dukungan Suami, Peran Petugas KB, Persepsi Masyarakat.

Sumber: Data diolah, 2021

Berdasarkan Tabel 10 hasil pengolahan data dapat dirumuskan sebagai berikut:

$$
\begin{aligned}
& \operatorname{Ln} \frac{\hat{p}}{1-\hat{p}}=-5,578+0,102 X_{1}-0,200 X_{2}+0,757 X_{3}+1,603 X_{4}-0,253 X_{5}+0,803 X_{6}
\end{aligned}
$$

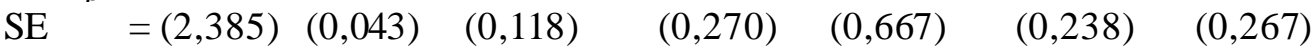

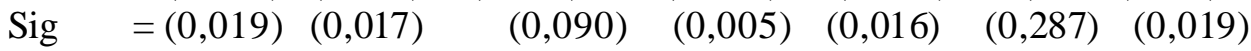

Berdasarkan hasil analisis pengaruh umur terhadap penggunaan alat kontrasep si diperoleh nilai signifikansi sebesar 0,017 dengan koefisien regresi sebesar 0,102, dan nilai wald sebesar 5,667. Nilai signifikansi 0,017 <0,05 menyatakan bahwa $\mathrm{H}_{0}$ ditolak, artinya variabel umur $\left(\mathrm{X}_{1}\right)$ berpengaruh positif dan signifikan terhadap penggunaan alat kontrasepsi di Kabupaten Badung. Nilai koefisien regresi logistik $\widehat{\beta_{1}}$ sebesar 0,102 memiliki arti apabila umur istri dari pasangan usia subur meningkat satu tahun dengan catatan variabel lain konstan, maka probabilitas keputu san pasangan usia subur untuk menggunakan alat kontrasepsi di Kabupaten Badung meningkat sebesar 0,525 atau 52,5 persen (data ini diperoleh dari $\frac{1}{1+e^{-0,102}}$ ).

Hal ini sesuai dengan penelitian oleh Musdalifah (2013) yang menyatakan bahwa ada hubungan yang signifikan antara umur dengan pemakaian kotrasepsi, sejalan pula dengan penelitian Dewi (2015) yang menunjukkan adanya hubungan yang signifikan antara usia ibu dengan penggunaan alat konrasepsi. Hasil penelitian ini didukung pula oleh penelitian Lontaan dan Kusmiyati (2014) hubungan umur dengan penggunaan alat kontrasepsi yang menunjukkan ad anya hubungan antara umur dengan penggunaan alat kontrasepsi. Penelitian yang sama dilakukan oleh Pramono dan Ulfa (2012) di Semarang dimana pada penelitiannya disebutkan bahwa ada hubungan antara umur dengan pemilihan kontrasepsi. Permintaan penggunaan alat kontrasepsi dengan u mur responden menunjukkan hubungan yang sangat bermakna.

Berdasarkan hasil analisis pengaruh tingkat pendidikan terhadap penggunaan alat kontrasepsi diperoleh nilai signifikansi sebesar 0,090 dengan nilai koefisien re gresi sebesar -0,200, dan nilai wald sebesar 2,873. Nilai signifikansi $0,090>0,05$ menyatakan bahwa $\mathrm{H}_{0}$ diterima, artinya variabel tingkat pendidikan $\left(\mathrm{X}_{2}\right)$ tidak berpengaruh signifikan terhadap penggunaan alat kontrasepsi di Kabupaten Badung. Hal tersebut dikarenakan hasil dari pengolahan data didapat bahwa masyarakat di Kabupaten Badung yang telah menjadi responden pengguna KB mayoritas merupakan lulu san SMA,

Analisis Faktor yang Mempengaruhi Keputusan Pasangan Usia Suburdalam Penggunaan Alat Kontrasepsi di 
sedangkan untuk responden bukan pengguna KB mayoritas merupakan lulusan Diploma/Perguruan Tinggi. Maka dari itu didapatkan hasil yang tidak signifikan dengan nilai koefisien regresi negatif.

Hasil penelitian ini sesuai dengan hasil penelitian Pramono dan Ulfa (2011) di Se marang yang menyatakan bahwa tidak ada hubungan yang signifikan antara tingkat pendidikan dengan penggunaan kontrasepsi. Hasil penelitian ini sejalan pula dengan hasil penelitian Pinontoan (2014) di Kabupaten Minahasa Utara bahwa tidak ada hubungan antara pendidikan ibu dengan penggunaan alat kontrasepsi, serta hasil penelitian Marikar (2015) di Kota Manado bahwa tidak ada hubungan an tara pendidikan dengan penggunaan alat kontrasepsi. Hasil penelitian ini bertentangan dengan hasil penelitian Rotie (2015),Handayani (2010) dalam Dewi dan Notobroto (2015), dan Yanuar (2010) yang mengatakan bahwa terdapat hubungan anatara tingkat pendidikan dengan penggunaan alat kontrasepsi. Berdasarkan tujuh penelitian tersebut tampak bahwa tidak selalu ada hubungan yang signifikan antara tingkat pendidikan dengan penggunan alat kontrasepsi. Hal ini dapat dipengaruhi oleh karakteristik dan jumlah responden dari setiap penelitian.

Berdasarkan hasil analisis pengaruh jumlah anak terhadap penggunaan alat kontrasepsi diperoleh nilai signifikansi sebesar 0,005 dengan nilai koefisien regresi sebesar 0,757 , dan nilai w ald sebesar 7,875. Nilai signifikansi $0,005<0,05$ menyatakan bahwa $\mathrm{H}_{0}$ ditolak, artinya variabel jumlah anak $\left(\mathrm{X}_{2}\right)$ berpengaruh positif dan signifikan terhadap pengguna an alat kontrasepsi di Kabupaten Badung. Nilai koefisien regresi logistik $\widehat{\beta_{3}}$ sebesar 0,757 memiliki arti apabila jumlah anak hidup dari pasangan usia subur bertambah satu orang dengan catatan variabel lain konstan, maka probabilitas keputusan pasangan usia subur untuk menggunakan alat kontrasepsi di Kabupaten Badung meningkat sebesar 0,681 atau 68,1 persen (data ini diperoleh dari $\frac{1}{1+e^{-0,757}}$ ).

Hasil penelitian ini sesuai dengan hasil penelitian Angoi (2012) dan Muatiara wati (2014) yang menyatakan bahwa terdapat pengaruh yang signifikan antara jumlah anak atau paritas den gan penggunaan alat kontrasepsi. Hasil penelitian ini sejalan pula dengan penelitian dari Dewiyanti (2020) di Puskesmas Bulak Banteng Surabaya yang menyatakan bahwa ada hubungan yang bermakna an tara jumlah anak yang dimiliki responden dengan penggunaan metode kontrasepsi.

Berdasarkan hasil analisis pengaruh dukungan suami terhadap penggunaan alat kontrase psi diperoleh nilai signifikansi sebesar 0,016 dengan nilai koefisien regresi sebesar 1,603, dan nilai wald sebesar 7,875. Nilai signifikansi $0,016<0,05$ menyatakan bahwa $\mathrm{H}_{0}$ ditolak, artinya variabel dukungan suami $\left(\mathrm{X}_{4}\right)$ berpengaruh positif dan signifikan terhadap penggunaan alat kontrasepsi di Kabupaten Badung. Nilai koefisien regresi logistik $\widehat{\beta_{4}}$ sebesar 1,603 memiliki arti apabila adanya dukungan suami dari pasangan usia subur, dengan catatan variabel lain konstan maka probabilitas keputusan pasangan usia subur untuk menggunakan alat kontrasepsi di Kabupaten Badung meningkat sebesar 0,833 atau 83,3 persen (data ini diperoleh dari $\frac{1}{1+e^{-1,603}}$ ).

Hasil penelitian ini sesuai dengan hasil penelitian Nuryati dan Fitria (2014) serta Tampubolon dan Tarigan (2018) yang menyatakan bahwa terdapat hubungan yang signifik an antara dukungan suami dengan penggunaan alat kontrasepsi. Hasil penelitian ini ju ga se suai dengan hasil penelitian Sudibia (2020) yang mengatakan bahwa terdapat hubungan antara dukungan suami dan penggunaan alat kontrasepsi pada wanita menikah usia dini.

Berdasarkan hasil analisis pengaruh peran petugas KB terhadap penggunaan alat kontrasepsi diperoleh nilai signifikansi sebesar 0,287 dengan nilai koefisien regresi sebesar - 0,253 dan nilai wald sebesar 1,132. Nilai signifikansi 0,287>0,05 menyatakan bahw a $\mathrm{H}_{0}$ diterima, artinya variabel peran petugas $\mathrm{KB}\left(\mathrm{X}_{5}\right)$ tidak berpengaruh signifikan terhadap penggunaan alat kontra sepsi di Kabu paten Badung. Hal ini dikarenakan hasil dari pengolahan data didapat bahwa jawaban dari responden terkait indikator-indikator yang menjadi tolak ukur untuk variabel peran petugas KB mayoritas yang menjawab setuju adalah responden bukan pengguna $\mathrm{KB}$, hal tersebut menyebabkan hubungan antara variabel peran petugas KB dengan penggunaan alat kontrasepsi tidak signifikan dan nilai koefisi en regresi menjadi negatif.

Hasil penelitian ini sejalan dengan hasil penelitian Asridawati (2019) di Kota Makasar yang mengatakan bahwa petugas KB sama sekali tidak mempengaruhi keputusanny a menggunakan alat

Analisis Faktor yang Mempengaruhi Keputusan Pasangan Usia Suburdalam Penggunaan Alat Kontrasepsi di 
kontrasepsi kecuali alat kontrasepsi yang telah dipilih menimbulkan efek samping karena petugas KB hanya berperan sebagai pemberi informasi. Hasil penelitian ini juga sejalan den gan hasil penelitian Zuhriyah, Lailatuz, (2012) dengan judul Revitalisasi Peran Petugas Lapangan Keluarga Berencana (PLKB) Dalam Meningkatkan Peserta Kelurga Berencana (KB) yang menyatak an bahwa meskipun pelayanan konseling KB telah diberikan, tetapi keputusan penggunaan alat kontrasep si tergan tung pada akseptor KB. Konselor hanya membantu menentukan pilihan yang tepat dan sesuai bagi mereka.

Berdasarkan hasil analisis pengaruh persepsi masyarakat terhadap penggunaan alat kontrasepsi diperoleh nilai signifikansi sebesar 0,003 dengan nilai koefisien regresi sebesar 0,803, dan nilai wald sebesar 9,080. Nilai signifikansi $0,003<0,05$ menyatakan bahwa $\mathrm{H}_{0}$ ditolak, artinya variabel persepsi masyarakat $\left(\mathrm{X}_{6}\right)$ berpengaruh positif dan signifikan terhadap penggunaan alat kontrasepsi di Kabupaten Badung. Nilai koefisien regresi logistik $\widehat{\beta_{6}}$ sebesar 0,803 memiliki arti apabila persepsi masyarakat mengenai manfaat KB bagi keluarga dari pasangan usia subur meningk at dengan catatan variabel lain konstan, maka probabilitas keputusan pasangan usia subur untuk menggunakan alat kontrasepsi di Kabupaten Badung meningkat sebesar 0,691 atau 69,1 persen (data ini diperoleh dari $\frac{1}{1+e^{-0,803}}$ ). Hasil penelitian ini sejalan dengan hasil penelitian Okfi Nurhanifah (2017) dan Sudibia (2020) yang menyatakan bahwa persepsi masyarakat memiliki hubungan yang positif dan signifikan dengan penggunaan alat kontrasepsi.

\section{SIMPULAN DAN SARAN}

Berdasarkan hasil pembahasan maka dapat disimpulkan bahwa umur, tingk at pendidikan, jumlah anak, dukungan suami, peran petugas $\mathrm{KB}$, dan persepsi masyarakat secara simultan berpengaruh signifikan terhadap penggunaan alat kontrasepsi di Kabupaten Badung. Umur, jumlah anak, dukungan suami, dan persepsi masyarakat secara parsial berpengaruh positif dan signifikan terhadap penggunaan alat kontrasepsi di Kabupaten Badung. Namun, tingkat pendidikan dan peran petugas KB secara parsial tidak berpengaruh signifikan terhadap penggunaan alat kontrasepsi.

Berdasarkan hasil penelitian dan simpulan diatas, maka dapat diajukan saran bahwa dari penelitian yang telah dilakukan masih diperlukannya pemberian informasi kepada para suami tentang jenis alat kontrasepsi, kelebihan dan kekurangan dari masing-masing alat kontrasepsi agar para suami juga mampu memahami tentang tujuan dan efek samping dari alat kontrasepsi. Sehingga suami menjadi lebih bisa memperhatikan kesehatan dari istrinya. Penyuluh KB saat memberikan sosialisasi sebaiknya lebih menekankan pada kelebihan dan kekurangan serta efek dari masing-masing alat kontrasepsi, dikarenakan sebagian besar responden yang memilih tidak menggunakan alat kontrasep si mengatakan bahwa responden tersebut takut pada efek-efek yang diberikan dan masih terdapat akseptor KB yang mengalami kehamilan walaupun sudah menggunakan alat kontrasepsi.

\section{REFERENSI}

Dewi, P. H. C., \& Notobroto, H. B. (2015). Rendahnya Keikutsertaan Pengguna Metode Kontrasepsi Jangka Panjang Pada Pasangan Usia Subur. Biometrika dan Kependudukan,3(1). 1-12

Dewiyanti, N. (2020). Hubungan Umur Dan Jumlah Anak Terhadap Penggunaan Metode Kontrasepsi Di Puskesmas Bulak Banteng Surabaya. Medical Technology and Public Health Journal, 4(1), 70-78.

Handayani, B., \& Rahmawati, N. I. (2016). Tingkat Pendidikan PUS Berhubungan dengan Pemilihan Jenis Alat Kontrasepsi tetapi Tidak Berhubungan dengan Keikutsertaan KB di Desa Argomulyo, Sedayu, Bantul, Yogyakarta. Jurnal Ners dan Kebidanan Indonesia, 4(1), 11-18.

Kühlbrandt, C. (2019). Confronting racism in family planning: a critical ethnography of Roma health mediation. Sexual and reproductive health matters, 27(1), 83-92.

Lontaan, A., \& Kusmiyati, K. (2014). Faktor-Faktor yang Berhubungan dengan Pemilihan Kontrasepsi Pasangan Usia Subur di Puskesmas Damau Kabupaten Talaud. JIDAN (Jurnal Ilmiah Bidan), 2(1), 27 32.

Analisis Faktor yang Mempengaruhi Keputusan Pasangan Usia Suburdalam Penggunaan Alat Kontrasepsidi 
Marikar, A. P. K., Kundre, R., \& Bataha, Y. (2015). Faktor-faktor Yang Berhubungan Dengan Minat Ibu Terhadap Penggunaan Alat Kontra sepsi Dalam Rahim (Akdr) Di Puskesmas Tuminting Kota Manado. Jurnal keperawatan, 3(2). 21-28

Nurhanifah, Okfi. (2017). Hubungan Persepsi Masyarakat Dengan Penggunaan Alat Kontrasepsi Keluarga Berencana Di Kelurahan Sempaja Selatan. Ejurnal Administrasi Negara, 5(2), 6026-6037

Pinontoan, S., Solang, S. D., \& Tombokan, S. G. (2014). Faktor-faktor yang berhubungan dengan penggunaan alat kontrasepsi dalam rahim di Puskesmas Tatelu Kabupaten Minahasa Utara. JIDAN (Jurnal Ilmiah Bidan), 2(2), 17-23

Qibthiyyah, R., \& Utomo, A. J. (2016). Family matters: Demographic change and social spending in Indonesia. Bulletin of Indonesian Economic Studies, 52(2), 133-159.

Rotie, N. M., Tombokan, S., \& Adam, S. K. (2015). Hubungan Pengetahuan dan Tingkat Pendidikan Ibu dengan Pengguna an Metode Kontra sepsi Efektif Terpilih. JIDAN (Jurnal Ilmiah Bidan), 3(1), 10-14

Saskara, I. A. G. D., \& Marhaeni, A. A. I. N. (2015). Pengaruh Faktor Sosial, Ekonomi, dan Demografi Terhadap Penggunaan Kontra sepsi di Denpasar. Jurnal Ekonomi KuantitatifTerapan.8(2), 155-161.

Setiasih, S., Widjanarko, B., \& Istiarti, T. (2016). Analisis Faktor-faktor yang Mempengaruhi Pemilihan Metode Kontrasepsi Jangka Panjang (MKJP) pada Wanita Pasangan Usia Subur (PUS) di Kabupaten Kendal Tahun 2013. Jurnal Promosi Kesehatan Indonesia, 11(2), 32-46

Sugiyono. 2010. 2015. 2017. Metode Penelitian Pendidikan (Pendekatan Kuantitatif, Kualitatif dan R\&D). Bandung: Alfabeta

Tampubolon, I. L., \& Tarigan, J. S. (2018). Hubungan Pengetahuan, Dukungan Suami dan Petugas Kesehatan dengan Penggunaan Alat Kontrasespsi Bawah Kulit (AKBK) pada Pasangan Usia Subur di Lingkungan II Kelurahan Nelayan Indah Keca matan Medan Labuhan. Jurnal Bidan Komunitas, 1(2), 58-66

Triyanto, L., \& Indriani, D. (2018). Faktor Yang Mempengaruhi Penggunaan Jenis Metode Kontra sepsi Jangka Panjang (MKJP) Pada Wanita Menikah Usia Subur Di Provinsi Jawa Timur. The Indonesian Journal of Public Health, 13(2), 246-257.

Winarni, E., \& Dawam, M. (2016). Family Planning Information, Education and Communication with Contraceptive Use. Kesmas: National Public Health Journal, 11(2), 94-102

Analisis Faktor yang Mempengaruhi Keputusan Pasangan Usia Suburdalam Penggunaan Alat Kontrasepsi di 